\title{
PENDIDIKAN AKUNTANSI FORENSIK DI INDONESIA: SEBUAH KAJIAN LITERATUR
}

\author{
FORENSIC ACCOUNTING EDUCATION IN INDONESIA: A LITERATURE REVIEW
}

Oleh:

\author{
Ratna Yudhiyati \\ Universitas Negeri Yogyakarta \\ ratna.yudhiyati@uny.ac.id
}

\begin{abstract}
Abstrak
Penelitian ini menganalisis secara sistematis artikel dan penelitian yang sudah ada tentang pendidikan akuntansi forensik di Indonesia. Penelitian ini juga hendak mengidentifikasi tren penelitian di bidang pendidikan akuntansi forensik untuk mengetahui peluang atau gap topik yang belum dibahas terkait dengan topik ini. Penelitian ini merupakan kajian literatur yang menggunakan metode narrative review dan descriptive review. Hasil penelitian ini menunjukkan bahwa semua pihak sepakat bahwa akan ada kenaikan permintaan akuntansi forensik yang mendorong mulai diajarkannya akuntansi forensik di bangku perguruan tinggi. Sayangnya, terdapat perbedaan pendapat tentang bagaimana pengajaran akuntansi forensik tersebut. Pelajar dan akademisi mendukung topik akuntansi forensik dileburkan pada mata kuliah lain, sedangkan praktisi lebih menginginkan mata kuliah yang terpisah. Penelitian lain merumuskan bahwa keahlian dan karakter yang perlu dibangun pada diri akuntan forensik di Indonesia dapat dibagi menjadi tiga atribut, yakni mentalitas, keahlian investigasi, dan pengalaman dalam menghadapi berbagai jenis kasus.
\end{abstract}

Kata kunci: kajian literatur, pendidikan akuntansi forensik, atribut akuntan forensik

\begin{abstract}
This study analyse existing studies and literatures concerning forensic accounting education in Indonesia. This study also seeks to identify research gap which can be explored in future studies. The design of this research is a literature review which utilize descriptive and narrative method in delivering the study's results. It can be concluded that main stakeholders in forensic accounting education perceive that there will be an increase of demand on forensic accounting service in the future. Thus, forensic accounting needs to be taught in undergraduate degree. However, most studies found that there was a differing opinion among academics, students, and practitioners (accountants). Academics and students prefer to integrate forensic accounting into existing courses, while accountants believe that the best way to teach forensic accounting is by putting it as a separate course. Other studies managed to identify necessary attributes for forensic accountants, which are mentality, scientific knowledge and technical skills, and experience.
\end{abstract}

Keywords: literature review, forensic accounting education, attributes of forensic accountant

\section{PENDAHULUAN}

Peningkatan skandal dan fraud keuangan di dunia bisnis selama beberapa dekade terakhir ini mendorong banyak negara ataupun pemangku kepentingan lain untuk mengambil 
langkah-langkah pencegahan dan penanggulangan. Salah satu topik yang semakin populer di banyak negara terkait dengan penanggulangan fraud keuangan adalah akuntansi forensik (Yusof, Kadir, \& Nor, 2007).

Akuntansi forensik adalah pengaplikasian teknologi dan ilmu pengetahuan di bidang akuntansi, keuangan, manajemen, dan krimilonologi untuk menginvestigasi dan menemukan bukti atas perbuatan terlarang dan penipuan (fraud) ataupun sengketa keuangan lain (Rezaee, Lo, Ha, \& Suen, 2016). Pendidikan terkait topik akuntansi forensik memungkinkan invididu yang pernah mempelajarinya untuk dapat mengidentifikasi indikator fraud (redflags) di organisasi dimana ia bekerja sekaligus memiliki pemahaman tentang langkah apa yang perlu dilakukan ketika hal tersebut ditemukan. Pendidikan akuntansi forensik pun menjadi semakin populer di berbagai negara seiring dengan kenaikan permintaan dari perusahaan ataupun organisasi untuk menghasilkan lulusan perguruan tinggi yang memiliki keahlian dan kesadaran anti-fraud.

Hasil survei yang dilakukan oleh Association of Certified Fraud Examiner menemukan bahwa tip atau informasi kecurigaan yang disampaikan oleh karyawan maupun pihak eksternal yang berinteraksi dengan perusahaan adalah sumber utama diidentifikasinya fraud organisasi (ACFE, 2020). Data ini menunjukkan bahwa pendidikan anti-fraud atau topik sejenis adalah fondasi penting bagi upaya penanggulangan fraud keuangan.

Situasi ini mendorong peneliti di beberapa negara untuk melakukan penelitian terkait dengan pendidikan akuntansi forensik. Beberapa penelitian berfokus pada persepsi masyarakat di suatu negara terhadap kebutuhan akuntansi forensik dan pendidikan akuntansi forensik yang telah berjalan di negara tersebut (Rezaee \& Burton, 1997; Rezaee et al., 2016; Yusof et al., 2007). Penelitian lain lebih spesifik menilai sejauh apa dan dalam bentuk apa pendidikan akuntansi forensik telah diterapkan (Meier, Kamath, \& He, 2010).

Hal menarik yang dapat diperoleh dari penelitian di berbagai negara ini adalah adanya kesamaan dan perbedaan yang cukup signifikan. Hasil penelitian Rezaee \& Burton (1997) menemukan bahwa akademisi dan praktisi bidang akuntansi di Amerika Serikat menilai bahwa akan terdapat kenaikan signifikan terhadap permintaan jasa akuntansi forensik di masa depan. Kesimpulan sejenis diperoleh juga oleh beberapa penelitian serupa yang dilakukan di Tiongkok (Rezaee et al., 2016) dan Malaysia (Yusof et al., 2007).

Namun, terdapat perbedaan kesimpulan terkait dengan kesiapan kurikulum akuntansi dalam mengakomodasi permintaan jasa akuntansi forensik tersebut. Hasil penelitian di Amerika Serikat menemukan bahwa praktisi dan akademisi menilai bahwa kurikulum akuntansi yang sudah ada masih belum mencukupi (Rezaee \& Burton, 1997). Akan tetapi, penelitian sejenis di Malaysia menemukan bahwa terdapat perbedaan pendapat antara praktisi dan akademisi, dimana akademisi menilai bahwa kurikulum yang ada sudah memadai sedangkan praktisi menganggap kurikulum yang ada belum memadai (Yusof et al., 2007).

Berbagai hasil penelitian ini menunjukkan terdapat perbedaan persepsi dan aplikasi pendidikan akuntansi forensik di berbagai negara. Akuntansi forensik di Amerika Serikat sudah cukup lama berkembang dibandingkan negara lain, sehingga penelitian di bidang pendidikan akuntansi forensik sudah cukup lama dilakukan di negara tersebut. Pertumbuhan ekonomi yang signifikan di banyak negara mengakibatkan kenaikan kebutuhan atas akuntansi forensik, tetapi penelitian di bidang ini masih jarang ditemukan di negara selain Amerika Serikat (Seda \& Kramer, 2014). Hal ini sangat disayangkan karena setiap negara memiliki karakter bisnis dan sistem tata kelola berbeda yang mengakibatkan kebutuhan atas akuntansi forensik yang berbeda antarnegara (Rezaee et al., 2016). Perbedaan ini dapat mengakibatkan kebutuhan yang berbeda atas pendidikan akuntansi yang paling tepat untuk suatu negara. Oleh karena itu, penelitian lokal terkait pendidikan akuntansi forensik menjadi suatu kebutuhan karena hasil penelitian sejenis di negara lain mungkin kurang relevan untuk negara yang berbeda. 
Masalah skandal dan fraud keuangan juga menjadi masalah besar di Indonesia. Indeks persepsi korupsi Indonesia pada tahun 2019 masih berada di peringkat 85 dari 180 negara (KPK, 2020). Survei yang dilakukan oleh ACFE (2020) juga menempatkan Indonesia sebagai negara dengan jumlah kasus fraud terhadap organisasi terbanyak di Asia Pasifik pada tahun 2019. Situasi ini mendorong bertumbuhnya kebutuhan atas profesi akuntan forensik. Investigasi dan audit forensik telah dilakukan untuk memperoleh bukti atas skandal keuangan Bank Century pada tahun 2011. Sayangnya, bukti yang diperoleh ditolak oleh DPR karena kualitas pekerjaan dianggap belum memadai (H. Y. Prabowo, 2013).

Semakin banyak perguruan tinggi di Indonesia yang menawarkan topik akuntansi forensik pada program akuntansi mereka. Akan tetapi, banyak institusi pendidikan tersebut yang belum memahami bahwa pendidikan akuntansi forensik mengandung masalah unik yang berbeda dengan pendidikan akuntansi keuangan biasa (H. Y. Prabowo, 2013). Masalah unik ini mendorong banyaknya penelitian tentang pendidikan akuntansi forensik di beberapa negara yang mencoba untuk membahas aspek-aspek yang berbeda. Beberapa penelitian ini telah direplikasi atau diadopsi di Indonesia, tetapi belum ada kesimpulan atau temuan yang bersifat konklusif tentang kondisi pendidikan akuntansi forensik di Indonesia.

Kajian literatur ini akan menganalisis penelitian yang sudah ada tentang pendidikan akuntansi forensik di Indonesia untuk mengetahui sejauh apa kesadaran dan penerapan pendidikan akuntansi forensik di Indonesia. Penelitian ini juga hendak mengidentifikasi tren penelitian di bidang pendidikan akuntansi forensik untuk mengetahui peluang atau gap topik yang belum dibahas terkait dengan pendidikan akuntansi forensik di Indonesia.

\section{METODE PENELITIAN}

\section{Desain Penelitian}

Penelitian ini adalah kajian literatur (literature review) yang menggunakan metode narrative review dan descriptive review. Kajian literatur yang menggunakan metode narrative review biasanya mengelompokkan objek penelitian berdasarkan metode penelitian, tema, atau hasil penelitian untuk kemudian dijabarkan dalam bentuk narasi (King, $\mathrm{He}$, \& Katz, 2005). Descriptive review lebih bersifat kuantitatif dibandingkan narrative review dimana penelitian yang menggunakan metode ini biasanya melakukan kodifikasi terhadap objek penelitian berdasarkan waktu publikasi, metodologi, teori, atau hasil, untuk kemudian melakukan analisis frekuensi terhadap hasil kodifikasi tersebut (King et al., 2005).

\section{Pengumpulan Data}

Penelitian ini menggunakan tahapan sistematis kajian literatur yang telah diterapkan oleh Spender, Corvello, Grimaldi, \& Rippa (2017) dan Pittaway, Robertson, Munir, Denyer, \& Neely (2004).

Pertama, penulis menentukan kata kunci yang akan digunakan sebagai basis pencarian awal artikel di database. Selanjutnya kata kunci tersebut disusun menjadi search string yang akan dimasukkan pada mesin pencari database. Kata kunci yang utama digunakan dalam pencarian adalah pendidikan forensik fraud mahasiswa akuntansi. Kata kunci kedua digunakan untuk pencarian tambahan dalam bahasa Inggris, yakni fraud education forensic accounting students Indonesia.

Pencarian dilakukan dua kali. Pencarian pertama menggunakan kata kunci bahasa Indonesia karena target artikel yang akan menjadi objek penelitian adalah artikel yang membahas tentang kondisi Indonesia. Pencarian tambahan dilakukan dengan menggunakan kata kunci bahasa Inggris untuk memastikan tidak ada artikel relevan yang terlewat. Pencarian dilakukan dengan menggunakan GoogleScholar dan portal Garuda (http://garuda.ristekbrin.go.id/) 
Kedua, penulis menentukan kriteria tambahan untuk menyeleksi lebih jauh hasil pencarian. Kriteria yang ditentukan adalah sebagai berikut.

1. Artikel dipublikasikan sejak tahun 2010.

2. Artikel yang hanya membahas tentang penerapan akuntansi forensik, tanpa membahas tentang aspek pendidikannya, dikeluarkan dari daftar objek penelitian.

Hasil pencarian awal dengan kata kunci utama dalam bahasa Indonesia dan syarat waktu publikasi sejak tahun 2010 memberikan hasil pencarian sebanyak 548 item di GoogleScholar, sedangkan hasil pencarian melalui portal Garuda menghasilkan dua item. Penulis memutuskan hanya akan memasukkan 100 hasil pencarian pertama di Google Scholar sebagai daftar calon objek penelitian dan seluruh hasil pencarian di portal Garuda. Pencarian tambahan dilakukan dengan meggunakan kata kunci bahasa Inggris. Dua puluh hasil pencarian pertama dimasukkan ke daftar calon objek penelitian. Pertimbangan ini dikarenakan GoogleScholar mengurutkan artikel berdasarkan sudut pandang seorang peneliti dengan mempertimbangkan kualitas artikel, kesesuaian tema, dan reputasi website. Oleh karena itu, artikel yang paling relevan hampir selalu muncul di halaman awal (Silic \& Back, 2014).

Pemilihan artikel lebih lanjut dilakukan dengan menggunakan kriteria (2) yang sudah dijelaskan sebelumnya. Berdasarkan metode pencarian tersebut, tujuh belas artikel yang memenuhi syarat berhasil dipilih. Artikel tersebut terdiri dari jurnal terindeks, jurnal belum terindeks, serta skripsi dan tesis mahasiswa.

\section{Teknik Analisis Data}

Metode yang akan digunakan pada penelitian ini adalah gabungan antara descriptive review dan narrative review. Pertama, penulis melakukan kodifikasi artikel berdasarkan teknik pengumpulan data, desain penelitian, sifat penelitian, lingkup sampel atau responden penelitian, dan topik penelitian. Kodifikasi dilakukan berdasarkan struktur yang sudah ditentukan di awal untuk mengurangi bias (Spender et al., 2017). Selanjutnya, analisis frekuensi akan dilakukan pada hasil kodifikasi tersebut.

Kedua, penulis mengelompokkan artikel sesuai dengan tingkat relevansi berdasarkan abstrak artikel tersebut (Pittaway et al., 2004). Penelitian ini membagi artikel tersebut dalam tiga daftar, yakni daftar A (10), B (5), dan C (2). Daftar A dan B terdiri dari artikel yang relevan dengan focus penelitian ini, tetapi artikel yang termasuk pada daftar B dianggap memiliki kekurangan terkait metode penelitian atau cara penulisannya yang berpotensi mengakibatkan bias saat analisis lebih jauh. Daftar C terdiri artikel yang lolos kriteria pemilihan yang sudah dijelaskan pada bagian sebelumnya, tetapi topik dan temuan artikel tersebut dinilai kurang relevan. Penulis lalu melakukan analisis tema terhadap artikel yang termasuk daftar A dan B dan menyajikan hasil penelitian secara naratif yang dibagi menjadi dua tema..

\section{HASIL PENELITIAN DAN PEMBAHASAN Analisis Deskriptif}

Penelitian ini menemukan bahwa dari 17 artikel yang dianalisis, 13 artikel mengumpulkan data atau informasi dengan metode kuesioner (76 persen), 3 artikel menggunakan metode interview (18 persen), dan 1 artikel memanfaatkan kombinasi metode interview dan database (6 persen). Jika data ini dibandingkan dengan pembagian artikel berdasarkan desain penelitian, dapat disimpulkan bahwa metode interview digunakan oleh penelitian kualitatif. Tabel 1 menunjukkan bahwa terdapat 4 penelitian kualitatif, 12 penelitian kuantitatif, dan 1 penelitian yang menggunakan metode gabungan (mixed method). Satu artikel yang menggunakan metode gabungan sebagai desain penelitiannya menggunakan metode interview untuk memperoleh data kualitatif yang dibutuhkan. 
Dilihat dari aspek sifat penelitian, lima belas artikel (88 persen) yang dipublikasi terkait dengan topik pendidikan akuntansi forensik bersifat empiris dan bertujuan untuk menguji hipotesis yang sudah ada. Hanya terdapat 2 artikel dari 17 artikel (12 persen) yang bersifat konseptual dan betujuan untuk membangun teori atau gagasan baru. Dua artikel yang bersifat

Tabel 1. Karakteristik Artikel yang Dianalisis

\begin{tabular}{lrlr} 
Metode Pengumpulan Data & & Sifat Penelitian & 15 \\
\hline $\begin{array}{l}\text { Kombinasi (Interview \& } \\
\text { database) }\end{array}$ & 1 & Empiris & 2 \\
\hline Kuesioner & 13 & Konseptual & \\
\hline Interview & 3 & & \\
\hline
\end{tabular}

\begin{tabular}{lclr}
\hline Desain Penelitian & & Lingkup Sampel/Responden & \\
\hline Kuantitatif & 12 & Kombinasi (Praktisi, Pelajar, Akademisi) & 3 \\
\hline Kualitatif & 4 & Akademisi dan Praktisi & 3 \\
\hline Campuran (Mixed) & 1 & Pelajar dan Akademisi & 2 \\
\hline & & Pelajar & 7 \\
\hline & Praktisi & 2
\end{tabular}

konseptual ini menggunakan desain metode penettian kualitatif dalam pengumpulan datanya. Data ini menunjukkan bahwa masih sedikit teori dan temuan baru terkait dengan topik pendidikan akuntan forensik. Mayoritas penelitian bersifat replikasi penelitian sebelumnya atau mengkonfimasi teori dan temuan yang sudah ada.

\section{Sebaran Topik Penelitian}

Tabel 2 menunjukkan bahwa sebanyak 7 artikel dari total 17 artikel (41 persen) mengangkat topik tentang persepsi terhadap pendidikan akuntansi forensik. Penelitian yang diidentifikasi mengangkat topik ini sebagian besar mereplikasi penelitian Rezaee \& Burton (1997) atau mengadopsi beberapa aspek dari penelitian tersebut.

Topik populer selanjutnya adalah identifikasi keahlian atau atribut yang harus diajarkan melalui pendidikan akuntansi forensi. Lima artikel dari 17 artikel (29 persen) mengangkat topik ini. Analisa lebih dalam terhadap lima artikel tersebut menemukan bahwa sebagian besar membahas tentang modul atau kurikulum pendidikan akuntansi forensik yang dirumuskan oleh Rezaee \& Burton (1997) atau variasi lain yang berfokus pada keahlian akuntansi dan pemahaman fraud keuangan. Satu artikel yang berbeda mencoba merumuskan tentang materi dasar hukum dan legalitas yang sebaiknya diajarkan pada mata kuliah akuntansi forensik (Rahmadania, 2018).

Dua artikel dari 17 artikel (12 persen) mengangkat topik menarik dimana mereka bertujuan mengidentifikasi metode pembelajaran terbaik untuk mengajarkan topik akuntansi

Tabel 2. Topik Penelitian

\begin{tabular}{lc}
\hline \multicolumn{1}{c}{ Topik Penelitian } & Frekuensi \\
\hline Dampak pendidikan akuntansi forensik terhadap etika & 3 \\
\hline Identifikasi Keahlian/Atribut yang harus dimiliki Akuntan Forensik & 5 \\
\hline Perspektif terkait Pendidikan Akuntansi Forensik & 7 \\
\hline Metode Pembelajaran Akuntansi Forensik & 2 \\
\hline
\end{tabular}

forensik di jenjang perguruang tinggi. Tiga artikel yang lain (18 persen) tidak secara langsung membahas tentang pendidikan akuntansi forensik. Mereka mencoba mengidentifikasi apakah 
keberadaan pendidikan akuntansi forensik di sebuah perguruan tinggi dapat mempengaruhi kesadaran fraud dan etika mahasiswa akuntansi di perguruan tinggi tersebut.

\section{Temuan dan Pembahasan}

Bagian berikut menjabarkan hasil analisis dan pembahasan terhadap isi dan temuan setiap artikel yang termasuk pada daftar A sesuai dengan penjelasan pada Teknik Analisis Data.

\section{Tema 1. Persepsi pemangku kepentingan tentang pendidikan akuntansi forensik di Indonesia}

Semua penelitian yang mengangkat topik evaluasi pendidikan akuntansi forensik di Indonesia mengidentifikasi akademisi, pelajar, dan praktisi sebagai pemangku kepentingan utama. Tiga pihak ini diidentifikasi sebagai pihak yang paling banyak berinteraksi dengan kebijakan pendidikan akuntansi forensik di Indonesia (Sofianti, Ludigdo, \& Irianto, 2014).

Seluruh artikel yang dianalisis menemukan bahwa tiga kelompok pemangku kepentingan tersebut sepakat bahwa akan ada kenaikan permintaan akuntansi forensik di masa depan (Dewajaya, 2016; Putra, 2018; Sofianti et al., 2014). Ekpektasi adanya kenaikan permintaan ini sama dengan temuan penelitian sejenis yang dilakukan di beberapa negara lain. Informasi ini menunjukkan bahwa kenaikan popularitas terhadap jasa akuntansi forensik terjadi di berbagai negara seiring dengan semakin kompleksnya transaksi bisnis dan berkembangnya fraud keuangan.

Sayangnya, artikel tersebut juga menilai bahwa kurikulum yang ada saat ini belum memadai untuk memenuhi kebutuan akuntansi forensik di Indonesia. Praktisi, akademisi, dan pelajar menekankan perlunya untuk memasukkan materi akuntansi forensik ke kurikulum akuntansi perguruan tinggi saat ini (A. Prabowo, 2015b; Sofianti et al., 2014).Hal ini serupa dengan temuan Meier et al. (2010) yang menemukan bahwa di program studi akuntansi yang sudah terakreditasi AACSB sekalipun masih sedikit perguruan tinggi yang sudah mengajarkan akuntansi forensik.

Analisis terhadap pemberlakuan mata kuliah akuntansi forensik di kurikulum akuntansi perguruan tinggi menemukan hasil yang kontradiktif. Secara umum, praktisi lebih menyarankan untuk mengajarkan akuntansi forensik sebagai mata kuliah tersendiri, sedangkan akademisi dan pelajar lebih mendukung topik akuntansi forensik dileburkan pada mata kuliah yang dianggap terkait, seperti pengauditan. Temuan ini serupa dengan kesimpulan penelitian terdahulu (Meier et al., 2010; Rezaee \& Burton, 1997). Akan tetapi, penelitian ini menemukan beberapa pengecualian. Beberapa penelitian menemukan responden akademisi yang juga mendukung pengajaran akuntansi forensik sebagai mata kuliah terpisah, walaupun mereka juga setuju jika akuntansi forensik dileburkan dengan mata kuliah lain (Putra, 2018; Rudhiansyah \& Irianto, 2014). Penelitian lain menemukan adanya praktisi yang lebih menyarankan untuk memasukkan topik akuntansi forensik ke mata kuliah lain (Sugianto \& Jiantari, 2014).

Analisis lebih dalam terkait isi beberapa artikel tersebut menemukan bahwa faktor familiaritas terhadap akuntansi forensik berperan besar terhadap perspektif responden. Akuntansi forensik masih belum banyak diajarkan di perguruan tinggi Indonesia dan hanya sebagian kecil praktisi yang pernah berkecimpung di bidang ini. Pemahaman terhadap akuntansi forensik dan topik yang terkait dapat mempengaruhi pandangan mereka terkait dengan urgenitas akuntansi forensik sebagai mata kuliah yang terpisah. Hal ini ditunjukkan oleh penelitian Rudhiansyah \& Irianto (2014) dimana penelitian ini menggunakan responden pelajar dan akademisi yang berada di perguruan tinggi yang mengajarkan akuntansi forensik sebagai mata kuliah terpisah. Pemahamanan lebih dalam tentang topik ini membuat responden mendukung mata kuliah akuntansi forensik diajarkan sebagai mata kuliah yang terpisah. 


\section{Tema 2. Pembelajaran Akuntansi Forensik}

Salah satu tantangan utama pengajaran akuntansi forensik di perguruan tinggi adalah tidak adanya standar yang baku dalam pemberian jasa akuntansi forensik maupun pemeriksaan fraud. Pemberian jasa akuntansi forensik dapat berbeda antarkasus tergantung situasi yang dihadapi oleh akuntan terkait. Karakter ini berbeda dengan jasa lain seperti pengauditan dimana sudah terdapat panduan tentang prosedur yang wajib dilakukan. Kondisi ini mempersulit pengurus program studi akuntansi dan pihak yang terkait dalam penyusunan kurikulum akuntansi forensik.

Tantangan ini menjadi semakin berat karena akuntansi forensik yang diekspektasikan oleh pemangku kepentingan dapat memiliki bentuk berbeda antarnegara. Akibatnya, acuan atau benchmarking dengan pendidikan akuntansi forensik di negara lain pun belum tentu dapat menjawab kebutuhan di Indonesia. Beberapa penelitian mencoba menjawab masalah ini dengan melakukan penelitian tentang materi atau topik akuntansi forensik yang relevan diajarkan di Indonesia.

Mayoritas artikel yang dianalisis menghasilkan kesimpulan yang serupa tentang keahlian atau topik akuntansi forensik yang perlu diajarkan pada mahasiswa. H. Y. Prabowo (2013) mengelompokkan berbagai keahlian dan karakter yang perlu dimiliki akuntan forensik tersebut menjadi tiga kelompok atribut, yakni (1) mentalitas, (2) keahlian investigasi, dan (3) pengalaman menghadapi berbagai jenis kasus. Pendidikan akuntansi forensik dan kurikulum yang terkait seharusnya disusun untuk memungkinkan peserta didik memiliki tiga atribut tersebut.

Atribut mentalitas sangat penting bagi akuntan forensik. Akuntan forensik membutuhkan keahlian kreatif, sifat kritis, nalar yang tajam, dan sifat ingin tahu untuk dapat menjalankan tugasnya (A. Prabowo, 2015a). Kompas moral yang kuat juga sangat penting bagi seorang akuntan forensik. Keahlian investigasi yang dibutuhkan oleh akuntan forensik juga sangat bervariasi. Beberapa keahlian tersebut terdiri dari kemampuan mengidentifikasi fraud dan pengecegahannya, keahlian pengumpulan bukti dan investigasi, teknologi informasi, dan kemampuan komunikasi lisan maupun tertulis (A. Prabowo, 2015a). Akuntansi forensik juga salah satu bidang keahlian dimana kemampuan multidisipliner sangat berperan, yakni terkait dengan akuntansi, bisnis, keuangan, psikologi, dan hukum (Rahmadania, 2018; Supriatna \& Apandi, 2017).

Tantangan dalam pembelajaran akuntansi forensik ini mendorong populernya model studi kasus (case study) sebagai model pembelajaran yang digunakan untuk pendidikan akuntansi forensik (Rudhiansyah \& Irianto, 2014; Saputra, 2019). Akuntansi forensik menekankan pentingnya pengalaman dan pemahaman atas praktik bisnis yang marak terjadi. Cara terbaik untuk memenuhi kebutuhan ini selama masa pendidikan adalah menyediakan berbagai contoh yang dapat dibahas di kelas oleh mahasiswa (Dewajaya, 2016). Model studi kasus dianggap efektif untuk mencapai sasaran yang diharapkan dalam pembelajaran akuntansi forensik.

\section{SIMPULAN DAN SARAN Simpulan}

Beberapa kesimpulan dapat diperoleh terkait dengan bagaimana pemangku kepentingan memandang urgenitas dan aplikasi pendidikan akuntansi forensik di Indonesia. Pertama, praktisi, akademisi dan pelajar sepakat bahwa akan ada kenaikan permintaan akuntansi forensik di masa depan. Sayangnya, mereka juga menilai bahwa kurikulum yang ada saat ini belum memadai untuk memenuhi kenaikan permintaan tersebut. Kedua, terdapat perbedaan pendapat tentang bagaimana bentuk integrasi akuntansi forensik ke kurikulum akuntansi. Pelajar dan akademisi cenderung mendukung topik akuntansi forensik dileburkan pada mata kuliah lain, 
sedangkan praktisi lebih menginginkan mata kuliah yang terpisah. Ada indikasi bahwa pemahaman terhadap akuntansi forensik dan seberapa jauh responden memiliki pengalaman terkait topik tersebut dapat mempengaruhi pandangan mereka terkait hal ini.

Beberapa penelitian mencoba merumuskan keahlian dan karakter yang perlu dibangun pada diri akuntan forensik di Indonesia. Keahlian dan karakter tersebut dapat dibagi menjadi tiga kategori atribut. Pertama, atribut mentalitas yang terkait dengan keahlian kreatif, sifat kritis, nalar yang tajam, sifat ingin tahu, dan kompas moral yang penting dimiliki oleh akuntan forensi. Kedua, keahlian investigasi yang terkait dengan kemampuan mengidentifikasi fraud dan pengecegahannya, keahlian pengumpulan bukti dan investigasi, teknologi informasi, kemampuan komunikasi, dan pengetahuan multidisipliner. Ketiga, pengalaman dalam menghadapi berbagai kasus yang berbeda. Atribut ketiga ini sulit untuk dimiliki oleh sarjana akuntansi yang baru saja lulus. Salah satu cara mempersiapkan mahasiswa akuntansi supaya mereka memiliki pengalaman dasar terkait hal ini adalah dengan mengintegrasikan contohcontoh aplikatif dalam pembelajaran. Oleh karena itu, model pembelajaran studi kasus menjadi model populer untuk pembelajaran akuntansi forensik.

\section{Peluang dan Saran}

Mayoritas penelitian di topik pendidikan akuntansi forensik baru sekedar mereplikasi penelitian sejenis di negara lain. Penelitian tersebut masih bersifat mengkonfirmasi atau menguji hipotesis, dimana temuan yang didapat cenderung sama dengan penelitian sebelumnya. Terdapat peluang topik yang belum terjamah terkait dengan penyusunan silabus atau kurikulum mata kuliah akuntansi forensik, maupun model pembelajaran yang relevan. Penelitian di topik ini masih sedikit dan temuan yang diperoleh akan sangat berdampak bagi peningkatan kualitas pendidikan akuntansi forensik di Indonesia.

Akuntansi forensik adalah ilmu yang sangat aplikatif dan cepat berubah sesuai dengan perkembangan bisnis. Akibatnya, pendidikan akuntansi forensik yang didesain oleh perguruan tinggi juga harus dapat menyesuaikan diri dengan tepat. Pendapat praktisi harus lebih dilibatkan dalam penyusunan kurikulum, silabus, atapun hal sejenis terkait dengan pendidikan akuntansi forensik bagi mahasiswa akuntansi.

\section{DAFTAR PUSTAKA}

ACFE. (2020). Report to the Nations: 2020 Global Study on Occupational Fraud and Abuse. Association of Certified Fraud Examiner.

Dewajaya, M. A. A. (2016). Persepsi Auditor Junior dan Auditor Senior terhadap Pendidikan Akuntansi Forensik (STIE Perbanas). Retrieved from http://eprints.perbanas.ac.id/672/1/ARTIKEL ILMIAH.pdf

King, W. R., He, J., \& Katz, J. H. (2005). Understanding the Role and Methods of MetaAnalysis in IS Research. Communications of the Association for Information Systems, 16(16), 665-686.

KPK. (2020). Indeks Persepsi Korupsi Indonesia Membaik. Retrieved May 15, 2020, from Komisi Pemberantasan Korupsi website: https://www.kpk.go.id/id/berita/beritakpk/1462-indeks-persepsi-korupsi-indonesia-membaik

Meier, H. H., Kamath, R. R., \& He, Y. (2010). Courses on Forensics and Fraud Examination in the Accounting Curriculum. Journal of Leadership, Accountability, and Ethics, 8(1).

Pittaway, L., Robertson, M., Munir, K., Denyer, D., \& Neely, A. (2004). Networking and innovation a systematic review of the evidence. International Journal of Management Reviews, 5(3), 137-168.

Prabowo, A. (2015a). Keahlian Akuntan Forensik dan Pendidikan Akuntansi Forensik di Indonesia. Integritas, 1(1), 111-135. 
Prabowo, A. (2015b). The perceived forensic accounting education development in Indonesia. International Journal of Applied Business and Economic Research, 13(7), 5501-5519.

Prabowo, H. Y. (2013). Better, faster, smarter: developing a blueprint for creating forensic accountants. Journal of Money Laundering Control, 16(4), 353-378.

Putra, M. A. (2018). Perbedaan Persepsi Akademisi dan Praktisi Akuntansi tentang Akuntansi Forensik sebagai Mata Kuliah. Jurnal STIE Semarang, 10(2), 1-21.

Rahmadania, F. (2018). Survei Atas Muatan Materi Hukum pada Mata Kuliah Akuntansi Forensik (Universitas Jember). Retrieved from http://repository.unej.ac.id/handle/123456789/88823

Rezaee, Z., \& Burton, E. J. (1997). Forensic accounting education: Insights from academicians and certified fraud examiner practitioners. Managerial Auditing Journal, 12(9), 479-489.

Rezaee, Z., Lo, D., Ha, M., \& Suen, A. (2016). Forensic Accounting Education and Practice: Insights From China. Journal of Forensic \& Investigative Accounting, 8(1), 106-119.

Rudhiansyah, \& Irianto, G. (2014). Pembelajaran Mata Kuliah Forensic Accounting dan Fraud Examination (Studi Kasus pada Jurusan Akuntansi Fakultas Ekonomi dan Bisnis Universitas Brawijaya Malang). Jurnal Ilmiah Mahasiswa FEB Universitas Brawijaya, $3(1), 1-25$.

Saputra, K. A. K. (2019). Case-Based Learning in Forensic Accounting Education. International Journal for Educational and Vocational Studies, 1(6), 545-553.

Seda, M., \& Kramer, B. K. P. (2014). An Examination of the Availability and Composition of Forensic Accounting Education in the United States and Other Countries. Journal of Forensic and Investigative Accounting, 6(1), 1-46.

Silic, M., \& Back, A. (2014). Information security: Critical review and future directions for research. Information Management and Computer Security, 22(3), 279-308.

Sofianti, S. P. D., Ludigdo, U., \& Irianto, G. (2014). The Perception of the Practitioners and Students towards the Subject of Forensic Accounting and Fraud Examination. Journal of Economics, Business, and Accountancy Ventura, 17(2), 281-292.

Spender, J. C., Corvello, V., Grimaldi, M., \& Rippa, P. (2017). Startups and open innovation: a review of the literature. European Journal of Innovation Management, 20(1), 4-30.

Sugianto, \& Jiantari. (2014). Akuntansi Forensik: Perlukah Ada dalam Kurikulum Jurusan Akuntansi. Jurnal Akuntansi Multiparadigma, 5(3), 345-510.

Supriatna, N., \& Apandi, R. N. N. (2017). Pengembangan Silabus Akuntansi Forensik bagi Mahasiswa Program Studi Akuntansi. Jurnal Riset Akuntansi Dan Keuangan, 5(2), 14951500.

Yusof, N. M., Kadir, D. A., \& Nor, M. N. M. (2007). Perception in Forensic Accounting Education in Malaysia: a Comparison Between Accounting Undergraduates and Practitioners. Indonesian Management \& Accounting Research, 6(2), 12-27. 